\title{
Medusahead Invasion as Influenced by Herbicides and Grazing on Low Sagebrush Sites ${ }^{1}$
}

\section{JAMES A. YOUNG AND RAYMOND A. EVANS}

Range Scientists, Plant Science Research Division, Agricultural Research Service, U.S. Department of Agriculture, Renewable Resource Center, University of Nevada, Reno, Nevada.

\section{Highlight}

Responses of vegetation following herbicide applications and grazing strengthened previously developed synecological concepts of the low sagebrush community in relation to medusahead invasion. Removal of the shrub cover with 2,4-D did not necessarily lead to an increase in medusahead because the perennial grasses quickly made use of the released environmental potential. Spraying 2,4-D for brush control combined with application of atrazine for herbaceous weed control further increased perennial grasses when not grazed, but with grazing, medusahead greatly increased at the expense of perennial grasses by 3 years after treatment.

Medusahead (Taeniatherum asperum (Sim.) Nevski) has been a highly successful invader of diverse plant communities since its introduction from Europe or Asia to southwestern Oregon late in the nineteenth century (McKcll et al., 1962; Turner et al., 1963). Medusahead has slowly progressed across the mountainous plateau of northeastern California until infestations are poised on the edge of the Great Basin bordering northeastern California and northern Nevada.

In a previous synecologic investigation we characterized soil and vegetation assemblages infested with medusahead on the margin of the Great Basin (Young and Evans, 1970). We determined that low sagebrush (Artemisia arbuscula Nutt.), communities were the most extensive communities subject to invasion by medusahead. Invasion by medusahead was dependent on the seral level of the community, with

\footnotetext{
${ }^{1}$ Received December 1, 1970; accepted for publication February 24, 1971. Cooperative investigation of the Plant Science Research Division, Agricultural Research Service, U. S. Department of Agriculture, and the Agricultural Experiment Station, University of Nevada, Reno, Nevada. University of Nevada Journal Series No. 174.
}

low sagebrush, perennial grass, and forb cover, all being negatively related to medusahead cover. Once medusahead gains a foothold in the community, the risk of wildfire and the destruction of shrub cover is greatly increased because of the accumulation of flammable fuel.

Our purposes were to test the relations between low sagebrush, perennial grass, or forb cover to medusahead invasion, and to determine if the herbicide 2-chloro-4-ethylamino-6-isopropylamino-s-triazine (atrazine) could be employed to prevent spread of medusahead in these communities.

\section{Methods}

We chose a modal low sagebrush community located near Adin, California. The area is locally known as Fly-Blown-Flat. The study area was located on a triangle of unfenced public land heavily grazed by cattle.

The vegetation was dominated by an overstory of low sagebrush. Located under the canopies of the shrubs were remnant clumps of the perennial grasses squirreltail ( $\mathrm{S}$ tanion hystrix (Nutt.) J. G. Sm.) and Sandberg bluegrass (Poa secunda Presl.). There was a colorful ephemeral vernal vegetation of bighead clover (Trifolium macro- cephalum (Pursh) Poir.), adobe beard-tongue (Penstemon laetus Gray), and Douglas phlox (Phlox douglasii Hook.). Panicle willowweed (Epilobium paniculatum Nutt.) and California goldenrod (Solidago californica Nutt.) formed a summer flora between the shrubs. During the remainder of the year the interspace among the shrubs was largely bare of vegetation.

Down slope from Fly-Blown-Flat wildfires have destroyed the low sagebrush cover and several thousand adjacent acres are dominated by medusahead, downy brome (Bromus tectorum L.), hairy chess (Bromus commutatus Schrad.) and redstem filaree (Erodium cicutarium (L.) L'Her.). Fly-Blown-Flat is directly in the path of medusahead invasion in terms of vegetation, continuous land form, and livestock movement. In the area of the investigation the annual grasses are largely restricted to areas of rodent disturbance, and pockets of vertisol clay with scant native vegetation.

Fly-Blown-Flat has a slight gilgai micro-relief. The mollic epipedon is a clay-loam and grades into a heavy clay argillic horizon. Below the clay is very indurate duripan. Soil depth to the pan ranges from 12 inches on the mounds to nothing in some of the swales.

The mean annual precipitation at Adin, 3 miles from the study area, is 18 inches. With a predominance of winter precipitation typical of the Intermountain West, Fly-Blown-Flat is a quagmire in the early spring and baked to a cracked brick consistency by late summer.

To fracture the structure of the community and to reduce it to a seral stage, we applied $2 \mathrm{lb}$./acre of propylene glycol butyl ether esters of (2,4-dichlorophenoxy)acetic acid $(2,4-D)$ in May 1967, following the procedures of Eckert and Evans (1968). The 2,4-D was applied in water to 20 by $20-\mathrm{ft}$ plots in a four replicated-randomized block design. An exclosure was constructed to prevent grazing and eight plots were sprayed inside and outside the exclosure. In October of 1967, we 
Table 1. Yield (lb./acre) and projected herbage cover (\%) of a low sagebrush community in relation to grazing and herbicide treatments. Treatments initiated in 1967 and sampled in 1970.a

\begin{tabular}{lccccc}
\hline \hline & & \multicolumn{4}{c}{ Projected herbage cover } \\
\cline { 3 - 6 } Treatments & Yield $^{\mathrm{b}}$ & $\begin{array}{c}\text { Perennial } \\
\text { grass }\end{array}$ & $\begin{array}{c}\text { Annual } \\
\text { grass }\end{array}$ & $\begin{array}{c}\text { Low } \\
\text { sagebrush }\end{array}$ & $\begin{array}{c}\text { Perennial } \\
\text { forbs }\end{array}$ \\
\hline Grazed & & & & & \\
$\quad$ Control & $300 \mathrm{~d}$ & $4 \mathrm{~b}$ & $3 \mathrm{~b}$ & $25 \mathrm{a}$ & $9 \mathrm{a}$ \\
2,4-D & $700 \mathrm{c}$ & $11 \mathrm{a}$ & $4 \mathrm{~b}$ & $\mathrm{~Tb}$ & $3 \mathrm{a}$ \\
2,4-D plus atrazine & $820 \mathrm{~b}$ & $3 \mathrm{~b}$ & $25 \mathrm{a}$ & 0 & $1 \mathrm{a}$ \\
Nongrazed & & & & & \\
Control & $480 \mathrm{~d}$ & $4 \mathrm{~b}$ & $4 \mathrm{~b}$ & $23 \mathrm{a}$ & $5 \mathrm{a}$ \\
2,4-D & $980 \mathrm{a}$ & $17 \mathrm{a}$ & $\mathrm{Tb}$ & $\mathrm{Tb}$ & $8 \mathrm{a}$ \\
2,4-D plus atrazine & $960 \mathrm{a}$ & $15 \mathrm{a}$ & $\mathrm{Tb}$ & $3 \mathrm{~b}$ & $3 \mathrm{a}$ \\
\hline
\end{tabular}

"Means followed by the same letter are not significantly different at 0.05 probability level as determined by Duncan's Multiple Range Test. All comparisons made vertically. b Dry matter from previous years production was not separated from perennial grass clumps during clipping. This is reflected in the relatively high production for this site. c $\mathrm{T}=$ less than $1 \%$ cover.

sprayed four inside and four plots outside the exclosure with $1 \mathrm{lb}$./ acre of atrazine. The treatments were applied in $10 \mathrm{gal} /$ acre of water. The same treatments were established in May and October of 1968 and 1969.

Each year (1967 through 1970), at maturity of the annual grasses, we clipped a 1-meter-square plot in each treatment. The projected herbage cover of the component herbaceous vegetation was estimated on each of these plots before clipping. Low sagebrush cover was estimated on the entire treatment area. The herbaceous vegetation was frequently sampled by using the steppoint method of Evans and Love (1957).

\section{Results}

The application of the herbicides and the initiation of the grazing treatments in 1967 induced a series of changes in the low sagebrush community. A comparison of these changes that have occurred by 1970 are presented. We suppressed succession with some of the treatments and they have and probably will continue to respond dynamically. The treatments initiated in 1968 and 1969 have induced the same pattern of changes in the community. In the interest of brevity we will present only the data with the longest time base.

The 2,4-D treatment in 1967, and all subsequent years, was almost completely effective in destroying the low sagebrush cover (Table 1). Cover of perennial grasses increased on all treatments where low sagebrush was removed except for grazed plots receiving the atrazine treatment. In 1970, on plots treated with 2,4-D and atrazine in 1967 and subsequently heavily grazed, the cover of annual grasses had increased. Change in the cover of perennial forbs was small and not statistically significant.

Removal of low sagebrush and protection from grazing resulted in about a three-fold increase in herbage yield over that obtained on the unsprayed and grazed area (Table 1). Production was the same on nongrazed 2,1-D treated plots whether atrazine was applied or not. Herbage yield of grazed plots where atrazine and 2,4-D were applied was markedly higher than the yield obtained from the 2,4-D treated and grazed treatments. Three years of non-use did not significantly increase herbage production on control treatments where the low sagebrush was not destroyed by 2,4-D.

Much of the herbage yield of the grazed plots treated with $2,4-\mathrm{D}$ and atrazine was composed of medusahead. The frequency as well as yield and cover of annual grasses, was markedly higher on these treatments (Table 2). On the nongrazed2,4-D-treated and 2,4-D and atrazinetreated plots, the frequency of annual grasses was much lower than on control plots.

The frequency of squirreltail increased on all plots where the low sagebrush cover was removed (Table 2). Atrazine treatments did not alter this increase in either the grazed or nongrazed condition. Squirreltail did not significantly increase in frequency with 3 years of non-use with an intact cover of low sagebrush. In contrast, Sandberg bluegrass markedly increased in frequency under these conditions. The

Table 2. Species composition (\%) based on frequency for a low sagebrush community in relation to herbicide and grazing treatments initiated in 1967 and sampled in 1970.a

\begin{tabular}{lccccc}
\hline \hline \multicolumn{1}{c}{ Treatments } & $\begin{array}{c}\text { Squirrel- } \\
\text { tail }\end{array}$ & $\begin{array}{c}\text { Sandberg } \\
\text { bluegrass }\end{array}$ & $\begin{array}{c}\text { Annual } \\
\text { grasses }\end{array}$ & $\begin{array}{c}\text { Panicle } \\
\text { willowweed }\end{array}$ & $\begin{array}{c}\text { Russian } \\
\text { thistle }\end{array}$ \\
\hline $\begin{array}{l}\text { Grazed } \\
\text { Control }\end{array}$ & $7 \mathrm{c}$ & $18 \mathrm{c}$ & $42 \mathrm{~b}$ & $33 \mathrm{a}$ & 0 \\
2,4-D & $30 \mathrm{~b}$ & $41 \mathrm{a}$ & $25 \mathrm{c}$ & $13 \mathrm{bcd}$ & 0 \\
2,4-D plus atrazine & $30 \mathrm{~b}$ & $4 \mathrm{~d}$ & $56 \mathrm{a}$ & $3 \mathrm{~d}$ & 7 \\
Nongrazed & & & & & \\
Control & $11 \mathrm{c}$ & $47 \mathrm{a}$ & $24 \mathrm{c}$ & $18 \mathrm{bc}$ & 0 \\
2,4-D & $41 \mathrm{a}$ & $23 \mathrm{bc}$ & $11 \mathrm{~d}$ & $25 \mathrm{~b}$ & 0 \\
2,4-D plus atrazine & $48 \mathrm{a}$ & $31 \mathrm{~b}$ & $11 \mathrm{~d}$ & $10 \mathrm{~cd}$ & 0
\end{tabular}

${ }^{a}$ Means followed by the same letter are not significantly different at the 0.05 probability level as determined by Duncan's Range Test. All comparisons are made vertically. 


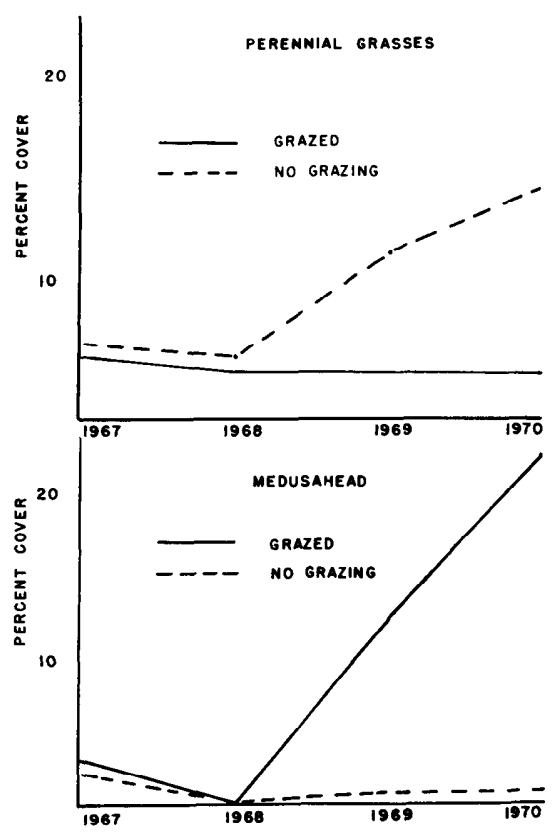

FIG. 1. Responses of perennial grass and medusahead cover for the period from 1967-1970 to applications of 2,4-D and atrazine in 1967.

application of $1 \mathrm{lb}$ /acre of atrazine to plots previously receiving an application of 2,4-D most reduced the frequency of Sandberg bluegrass if the treated area was grazed.

The grazed 2,4-D and atrazine treatment also most reduced the frequency of panicle willowweed, the major component of perennial forb cover (Table 2). This was the only treatment where the seral status of the community was sufficiently suppressed to allow the establishment of Russian thistle (Salsola kali L. var. tenuifolia Tausch.).

The grazing exclosure was constructed in May, 1967 at the time of the initial 2,4-D treatments. By the time the atrazine was applied in October, the perennial grasses had completed reproduction without grazing while outside the exclosure the grasses were heavily grazed. During the growing season of 1968 , the atrazine treated areas, both grazed and ungrazed, were completely free of annual vegetation (Fig. 1). Perennial grasses in the grazed treatments developed severe symptoms of atrazine injury. The typical chlorosis of leaves was espe-

Table 3. Relation of medusahead cover to low sagebrush, perennial grass, and perennial forb cover based on a previous synecological studya and manipulation of the community with herbicides.

\begin{tabular}{|c|c|c|c|}
\hline & \multicolumn{3}{|c|}{ Medusahead cover ${ }^{b}$} \\
\hline & $\mathrm{r}$ & $\mathrm{a}$ & b \\
\hline \multicolumn{4}{|l|}{ Low sagebrush cover } \\
\hline Previous synecological study & $-0.80 * *$ & 24.38 & -0.2714 \\
\hline This investigation & $-0.79 * *$ & 21.23 & -0.2431 \\
\hline \multicolumn{4}{|l|}{ Perennial grass cover } \\
\hline Previous synecological study & $-0.68 * *$ & 21.33 & -0.2237 \\
\hline This investigation & $-0.54 * *$ & 12.91 & -0.7472 \\
\hline \multicolumn{4}{|l|}{ Native forb cover } \\
\hline Previous synecological study & $-0.62 * *$ & 13.37 & -0.1135 \\
\hline This investigation & $-0.51 * *$ & 5.34 & -0.1587 \\
\hline
\end{tabular}

cially evident on Sandberg bluegrass plants growing in swale areas where soil depth to the indurate pan was at a minimum. The grazed, atrazine-treated perennials failed to reproduce in 1968. Symptoms of atrazine injury were hardly evident in perennial grasses on the nongrazed treatments and caryopses production was heavy.

In 1969, following the year of atrazine activity, medusahead greatly increased on grazed plots, but only an occasional plant of this species was found in the nongrazed plots (Fig. 1). Total perennial grass cover remained relatively stable on the grazed plots following the year of atrazine activity. However, frequency sampling indicated that Sandberg bluegrass was replaced by squirreltail on these plots. In contrast, following the year of atrazine activity, perennial grass covcr greatly increased on the nongrazed plots.

There is close agreement between the correlation coefficients and partial regression equations for the relation between low sagebrush cover and medusahead cover developed by our previous synecological investigation and by this artificially manipulated community (Table 3). Similar trends are also apparent for the relation between perennial grass or forb cover and medusahead cover. For the two latter characteristics the mean cover for Fly-Blown-Flat was lower than the means obtained from the extensive synecological study.

\section{Summary and Discussion}

As long as the shrub cover remains, low sagebrush communities are relatively resistant to invasion by medusahead. Removal of the shrub cover with 2,4-D does not necessarily lead to an increase in medusahead if the perennial grasses quickly make use of the released environmental potential. In this study, the perennial grasses suppressed any marked increase in medusahead even when continuous heavy grazing followed removal of the brush.

Applications of $1 \mathrm{lb}$./acre of atrazine eliminated all annual vegetation the year following application. On heavily grazed plots treated with 2,4-D and atrazine, there was severe injury to the native perennial grasses followed by an increase of medusahead. In contrast, on nongrazed plots, the atrazine treatment significantly increased perennial grasses, with only an occasional medusahead plant present. 
This study confirms the information developed in a previous synecological investigation that a stable perennial grass/low sagebrush community is an effective barrier against medusahead invasion. We need grazing studies to know how much of the perennial grass can be harvested and still prevent medusahead invasion.

\section{Literature Cited}

ECKert, R. E., JR., ANd R. A. Evans. 1968. Chemical control of low sagebrush and associated green rabbitbrush. J. Range Manage. 21:325328.

Evans, R. A., ANd R. M. Love. 1957. The step-point method of sampling -A practical tool in range research. J. Range Manage. 10:208-212.

McKell, C. M., J. P. Robison, and J.
MAJOR. 1962. Ecotypic variation in medusahead an introduced annual grass. Ecology 43:686-698.

Turner, R. B., C. E. Poulton, And W. L. Gould. 1963. Medusahead-A threat to Oregon rangeland. Agr. Exp. Sta., Oregon State Univ., Special Report 149. 21 p.

Young, J. A., AND R. A. Evans. 1970. Invasion of mcdusahead into the Great Basin. Weed Sci. 18:89-97. 